\title{
Hubungan Kinerja Pustakawan dengan Kepuasan Pengguna Studi Kasus pada Perpustakaan SMK Negeri 1 Ngablak
}

\author{
Pilih Wahyuningsih \\ SMK Negeri 1 Ngablak Magelang \\ email: piriwahyuningsih@gmail.com
}

\section{Abstrak}

Kepuasan pengguna merupakan salah satu tujuan yang harus dicapai dalam menjalankan pelayanan perpustakaan. Kepuasan pengguna dapat diukur dari pelayanan yang diberikan oleh pustakawannya. Pelayanan pustakawan merupakan bagian dari kinerja pustakawan. Seorang pustakawan seharusnya bisa memberikan pelayanan yang baik untuk pengguna perpustakaan. Studi ini bertujuan untuk mengetahui sejauh mana hubungan kinerja pustakawan dengan kepuasan pengguna di Perpustakaan SMK Negeri 1 Ngablak. Metode yang digunakan untuk mendapatkan data ialah melalui wawancara yang dilakukan terhadap 30 siswa. Hasil yang didapatkan adalah, secara keseluruhan kualitas layanan di perpustakaan SMK Negeri 1 Ngablak sudah memberikan kepuasan pada pengguna perpustakaan. Kinerja pustakawan dianggap sudah cukup bagus dan memuaskan para pengguna perpustakaan. Faktor yang dianggap sebagai penyebab rendahnya kepuasan pengguna berasal dari luar, yaitu pihak sekolah secara umum. Kesimpulan yang dapat diambil dari studi ini ialah, semakin baik kinerja pustakawan maka semakin tinggi tingkat kepuasan pengguna di Perpustakaan SMK Negeri 1 Ngablak.
\end{abstract}

\section{Kata Kunci:}

pelayanan perpustakaan kinerja pustakawan kepuasan pengguna perpustakaan

\section{A. PENDAHULUAN}

Di era moderen ini, informasi merupakan sebuah kebutuhan bagi sebagian besar manusia. Informasi sebagai kepentingan pokok, yang banyak dicari oleh umat manusia, sebagai sumber utama dalam menghadapi era persaingan global ini. Pemenuhan akan kebutuhan informasi menjadi hal yang mutlak. Hal itu setara dengan kebutuhan pokok manusia akan pangan, sandang dan papan, serta kebutuhan akan pendidikan dan kesehatan. Seseorang dengan wawasan dan ilmu pengetahuan luas akan mampu menjawab berbagai masalah dan tantangan global. Hanya orang dengan informasi luas yang akan mampu bersaing dalam dunia pendidikan maupun dunia kerja. Orang yang tidak memilliki informasi akan ketinggalan zaman karena tidak tahu dengan hal-hal yang sudah terjadi di sekelilingnya.

Perpustakaan merupakan salah satu sumber informasi yang menyediakan bahan-bahan ilmiah dan pengetahuan lainnya. Dengan ilmu pengetahuan sebagai sumber-sumber dasarnya, perpustakaan berperan khusus dalam kehidupan manusia sebagai upaya untuk mengangkat derajat kehidupan ke tingkat yang lebih baik. Perpustakaan harus dapat melaksanakan pelayanan dan menyediakan sumber-sumber informasi yang sesuai dengan tingkat pendidikan, selera dan kebutuhan masyarakat pemakai sehingga perpustakaan dapat menjelma sebagai pusat sumber belajar.

Salah satu komponen penting dalam perpustakaan adalah pelayanan perpustakaan. Layanan di perpustakaan tidak hanya tentang peminjaman koleksi, tetapi juga termasuk pengadaan tempat membaca yang nyaman, serta didukung dengan adanya bahan pustaka yang sesuai dan adanya staf perpustakaan yang handal. Ada banyak hal yang menyebabkan keberhasilan pelayanan di perpustakaan. Diantaranya adalah hal yang berkaitan dengan pengelolaan oleh petugas 
perpustakaan baik dalam hal layanan ataupun teknis. Hal ini erat sekali kaitannya dengan kualifikasi dan kuantitas petugas perpustakaan yang dimiliki oleh setiap perpustakaan. Petugas perpustakaan merupakan motor penggerak terhadap kegiatan yang ada di perpustakaan.

Pelayanan perpustakaan yang baik sangat erat kaitannya dengan kualitas pustakawan itu sendiri. Pustakawan selalu berhubungan dengan pengguna perpustakaan baik secara langsung maupun tidak langsung. Itulah sebabnya petugas perpustakaan merupakan daya tarik tersendiri bagi pemakai untuk selalu menggunakan perpustakaan. Untuk menjadi pustakawan yang baik memerlukan beberapa persyaratan antara lain memiliki sikap yang ramah, sopan, kreatif, memiliki pengetahuan luas, dan menguasai teknik-teknik pelayanan. Oleh sebab itu layanan perpustakaan termasuk syarat pokok agar tercapai tujuan dari perpustakaan. Tanpa pelayanan yang baik, sudah pasti tujuan perpustakaan akan gagal.

Perpustakaan yang menjadi kajian penulis adalah perpustakaan SMK Negeri 1 Ngablak. Petugas di perpustakaan SMK Negeri 1 Ngablak meliputi seorang pustakawan yang berpendidikan D2 Ilmu Perpustakaan dan satu kepala perpustakaan yang memiliki latar belakang pendidikan S1 Bahasa Indonesia dan telah mengikuti diklat perpustakaan. Perpustakaan SMK Negeri 1 Ngablak menerapkan sistem layanan terbuka. Dimana pemustaka dapat langsung mencari koleksi yang diinginkannya di dalam rak-rak koleksi yang tersedia di perpustakaan.

Dalam tulisan ini akan dibahas tentang hubungan antara kinerja pustakawan dengan kepuasan pengguna perpustakaan di SMK Negeri 1 Ngablak. Melalui karya ilmiah ini penulis mengharapkan pembaca mengetahui gambaran tentang hubungan kinerja pustakawan terhadap kepuasan pengguna perpustakaan. Selain itu agar diketahui kelemahan pustakawan dalam melayani penggunanya, sehingga dapat diperbaiki kelemahan-kelemahan tersebut untuk mencapai pelayanan perpustakaan yang bagus serta dapat memberikan kepuasan pada para pengguna perpustakaan.

\section{B. KAJIAN TEORITIS}

Perpustakaan adalah suatu unit kerja dari suatu badan atau lembaga tertentu yang mengelola bahan-bahan pustaka, baik berupa buku-buku maupun bukan berupa buku (non book material) yang diatur secara sistematis menurut aturan tertentu sehingga dapat digunakan sebagai sumber informasi oleh setiap pemakainya (Bafadal, 2006). Perpustakaan sekolah adalah perpustakaan yang tergabung pada sebuah sekolah, dikelola sepenuhnya oleh sekolah yang bersangkutan, dengan tujuan utama membantu sekolah untuk mencapai tujuan khusus sekolah dan tujuan pendidikan pada umumnya (Basuki, 2010).

Pustakawan adalah orang dengan pekerjaan yang berkaitan erat terhadap dunia perpustakaan, dengan meliputi pengolahan bahan pustaka, pelayanan pengguna perpustakaan dan penyampai informasi. Pemustaka adalah pemakai perpustakaan secara individu ataupun berkelompok yang menggunakan fasilitas dan koleksi bahan pustaka serta memanfaatkan layanan yang ada di perpustakaan.

Kinerja pustakawan merupakan keberhasilan seseorang secara menyeluruh dalam menyelesaikan tugas dan pekerjaannya yang berkaitan dengan kualitas, kuantitas, mampu bekerja sama dan memahami tugasnya, serta disiplin dan mampu meningkatkan potensi diri, serta didukung semangat kerja yang tinggi.

\section{METODE PENELITIAN}

Metode yang digunakan dalam kajian ini adalah metode kualitatif. Teknik pengumpulan data dilakukan dengan cara wawancara. Penelitian dilakukan di SMK Negeri 1 Ngablak dengan 
Hubungan Kinerja Pustakawan dengan Kepuasan Pengguna Studi Kasus pada Perpustakaan SMK Negeri 1 Ngablak

P. Wahyuningsih

mengambil sampel sebanyak 30 orang siswa sebagai respondennya. Penelitian dilakukan dari tanggal 30 September 2019 sampai dengan tanggal 12 Oktober 2019.

\section{HASIL DAN PEMBAHASAN}

Pelayanan merupakan bagian dari perpustakaan. Layanan bermakna kegiatan. Koleksi di perpustakaan harus selalu ada untuk pemakai yang membutuhkannya.Tanpa pelayanan tidakakan terbentuk perpustakaan. Akan tetapi perpustakaan juga tidak akan berjalan kalau tidak ada pengguna yang memanfaatkan sumber-sumber informasi yang tersimpan di perpustakaan. Kepuasan pemakai perpustakaan termasuk salah satu bagian dari pelayanan pemustaka. Besarnya kepuasan pemustaka merupakan keberhasilan pelayanan perpustakaan. Untuk memenuhi kepuasan para pengguna perpustakaan maka diperlukan banyak masukan-masukan positif dari para pengguna perpustakaan untuk kemajuan perpustakaan.

Sikap pustakawan yang ramah dan sopan juga menunjang kepuasan pengguna perpustakaan. Selain itu pustakawan hendaknya juga mempunyai wawasan yang banyak serta mengetahui teknikteknikpelayananbahan pustaka,agarparapengguna perpustakaan merasa puas. Pelayanan koleksi yang ada di perpustakaan SMK Negeri 1 Ngablak menerapkan sistem layanan sirkulasi, layanan referensi, dan layanan ruang baca. Layanan sirkulasi adalah kegiatan penulisan untuk menunjukkan bahwa pemakai menggunakan bahan pustaka, agar pemakai dapat menggunakan koleksi dengan tepat. Layanan sirkulasi memperhitungkan cara yang paling praktis agar pelayanan dapat tercapai dengan waktu, tenaga dan biaya efisien. Layanan referensi merupakan pelayanan langsung kepada pengguna dengan menyampaikan informasi dan mencarikan bahan pustaka yang dibutuhkan oleh pemustaka. Sedangkan pelayanan ruang baca yaitu pelayanan dengan menyediakan ruangan untuk pengunjung yang hanya membaca di tempat dan tidak bermaksut meminjam bahan pustaka untuk dibawa pulang.

Perpustakaan SMK Negeri 1 Ngablak telah menyediakan fasilitas tempat untuk pengguna yang berupa kursi, meja baca pribadi dan meja baca besar untuk kegiatan diskusi kelompok. Kegiatan pelayanan bahan pustaka di perpustakaan SMK Negeri 1 Ngablak menggunakan metode pelayanan terbuka. Para pemustaka dapat memilih dan mencari koleksi yang diperlukan di tempat yang telah tersedia. Menurut hasil riset kepada 30 orang siswa, $81 \%$ siswa menyatakan bahwa kinerja pustakawan di perpustakaan SMK Negeri 1 Ngablak cukup baik dan memuaskan. Hal itu meliputi $27 \%$ tentang sikap ramah dan sopan dari pustakawannya. 31\% menyatakan bahwa pustakawan telah memiliki pengetahuan yang luas. Sedangkan sisanya yaitu 23\% responden menyatakan bahwa pustakawan telah menguasai teknik-teknik pelayanan perpustakaan.

Dari 30 siswa yang menjadi sampel, 19\% responden menyatakan bahwa mereka kurang puas dengan kinerja pustakawan. Petugas dirasa kurang kreatif dalam menciptakan ruangan perpustakaan yang bagus dan nyaman. Selain itu karena petugasnya hanya satu, menjadikan para siswa merasa kurang puas dalam pelayanan. Apalagi disaat petugas ijin tidak masuk, para siswa tidak ada yang melayani. Sedangkan kepala perpustakaan karena latar belakangnya seorang guru, maka lebih banyak mengajar daripada di dalam perpustakaan. Sehingga siswa tidak bisa memaksimalkan pemanfaatan bahan pustaka yang ada. Berdasarkan hasil riset diketahui bahwa petugas perpustakaan harus menambah kreatifitasnya untuk membuat perpustakaan menjadi termpat yang nyaman dan indah. Sehingga para pengguna merasa betah dan krasan untuk berlama-lama di perpustakaan. Selain itu juga perlu kerjasama dengan pihak sekolah untuk mengusahakan penambahan tenaga pustakawan, 
agar pelayanan perpustakaan bisa lebih maksimal dan memuaskan para pengguna perpustakaan di SMK Negeri 1 Ngablak.

Secara umum kinerja pustakawan di perpustakaan SMK Negeri 1 Ngablak sudah cukup baik dan memuaskan. Hal ini terbukti dengan $81 \%$ responden yang menyatakan kepuasannya pada kinerja sang pustakawan. Meskipun begitu sebagai pustakawan yang baik harus tetap berbenah diri dengan meningkatkan kualitasnya, agar pelayanan di perpustakaan SMK Negeri 1 Ngablak semakin baik.

Hasil penelitian ini didukung oleh hasil riset dari Fang Ju dan Jia Tina Du yang menyatakan, bahwa dibandingkan dengan mahasiswa sarjana, mahasiswa pascasarjana lebih puas dengan kualitas sistem perpustakaan digital, kualitas informasi, dan kualitas layanan, afinitas, persepsi kemudahan penggunaan, dan persepsi manfaat (Ju \& Du, 2019). Perbedaan individual pengguna, seperti usia, frekuensi penggunaan dan pengalaman penggunaan, memiliki dampak signifikan pada kepuasan mahasiswa sarjana dan pascasarjana dengan perpustakaan digital. Pustakawan universitas dan penyedia layanan harus memperhatikan persamaan dan perbedaan antara kepuasan mahasiswa sarjana dan pascasarjana dengan perpustakaan digital, dan meningkatkan sistem, informasi dan kualitas layanan perpustakaan digital untuk meningkatkan persepsi kemudahan penggunaan, persepsi manfaat, dan afinitas perpustakaan digital. , dengan demikian untuk meningkatkan kepuasan pengguna. Masih menurut Fang Ju dan Jia Tina Du memberikan penjelasan dari hasil risetnya menunjukkan bahwa, alih-alih kualitas informasi, sistem dan kualitas layanan secara signifikan memengaruhi persepsi kemudahan penggunaan, persepsi manfaat dan afinitas perpustakaan digital (Ju \& Du, 2018). Baik persepsi kemudahan penggunaan maupun afinitas perpustakaan digital berdampak pada manfaat yang dirasakan.

Selain itu, manfaat yang dirasakan dan afinitas perpustakaan digital memiliki efek signifikan pada kepuasan pengguna, sehingga mempengaruhi loyalitas pengguna. Kami juga menemukan bahwa perbedaan pengguna, termasuk usia, jenis kelamin, dan tingkat pendidikan, secara signifikan memengaruhi afinitas perpustakaan digital, yang selanjutnya memengaruhi kepuasan dan loyalitas pengguna. Implikasi untuk pustakawan dan penyedia layanan untuk meningkatkan kualitas perpustakaan digital disediakan. Sementara Muhammad Sajid Mirza dan Khalid Mahmood dari hasil penelitiannya menyimpulkan bahwa kepuasan pemustaka dipengaruhi oleh kualitas sumber daya dan layanan elektronik yang efektif kepada penggunanya (Mirza \& Mahmood, 2012). Selanjutnya Cagri Immogu dan Meltem O. Gurel menjelaskan dalam menanggapi keluhan dari pengguna perpustakaan tentang kurangnya ruang kerja di ruang perpustakaan universitas selama periode sibuk (Immogu \& Gurel, 2016). Sebuah studi pemetaan perilaku dan survei yang melibatkan 78 siswa menyarankan bahwa tabel di aula perpustakaan digunakan secara tidak efisien, terutama karena kebutuhan akan kode wilayah. Oleh karena itu, peneliti mengusulkan desain dan penggunaan tabel baru yang menyediakan pembagian ruangan dan desain ruangan perlu diimplementasikan oleh administrator universitas. Penelitian lanjutan dengan 86 siswa menunjukkan bahwa perbaikan desain tidak hanya menyebabkan adanya perubahan tren preferensi tempat duduk ke arah penggunaan ruang belajar yang lebih efisien, tetapi juga meningkatkan kepuasan pengguna.

\section{E. PENUTUP}

\section{Simpulan}

1. Layanan koleksi di perpustakaan SMK Negeri 1 Ngablak cukup bagus, sesuai dengan keinginan para pemakai perpustakaan. Hal ini 
Hubungan Kinerja Pustakawan dengan Kepuasan Pengguna Studi Kasus pada Perpustakaan SMK Negeri 1 Ngablak

sesuai dengan respon pemakai pada petugas perpustakaan yang cukup ramah dan sopan dalam pelayanan pemakai.

2. Sudah banyak pengguna perpustakaan yang berpersepsi bahwa pustakawan telah memiliki pengetahuan yang luas, serta mengetahui teknik-teknik pelayanan bahan pustaka dengan cukup baik.

3. Kreatifitas pustakawan perlu di pupuk dan ditingkatkan lagi.

\section{Saran}

1. Petugas perpustakaan sebaiknya menambah kreatifitasnya agar perpustakaan menjadi semakin bagus dan maju.

2. Pustakawan harus mampu berkomunikasi dengan pihaksekolah agar bisa mengusahakan anggaran untuk mempercantik kondisi perpustakaan dan menambah sarana prasarananya.

3. Perpustakaan harus mampu menjalin komunikasi dengan pihak sekolah untuk mengusahakan penambahan staf perpustakaan, agar pekerjaan di perpustakaan berjalan lancar dan tidak terbengkelai.

\section{DAFTAR PUSTAKA}

Bafadal, I. (2006). Pengelolaan Perpustakaan Sekolah. Jakarta: Bumi Aksara.

Basuki, S. (2010). Pengantar Ilmu Perpustakaan. Jakarta: Gramedia Pustaka Utama.

Immogu, C., \& Gurel, M. O. (2016). Good Fences Make Good Neighbors": Territorial Dividers Increase User Satisfaction and Efficiency in Library Study Spaces. The Journal of Academic Librarianship, 42(1), 65-73.

Ju, F., \& Du, J. T. (2018). Factors influencing users' satisfaction and loyalty to digital libraries in Chinese universities. Computers in Human Behavior, 83, 64-72.

Ju, F., \& Du, J. T. (2019). Examining differences and similarities between graduate and undergraduate students' user satisfaction with digital libraries. The Journal of Academic Librarianship, 45(6).

Mirza, M. S., \& Mahmood, K. (2012). Electronic resources and services in Pakistani university libraries: A survey of users' satisfaction. The International Information \& Library Review, 44(3), 123-131. 